\title{
Race is on to find alternative to animal tests
}

\section{Sally Goodman, Paris}

Plans to test systematically the toxicity of thousands of chemicals that are widely used in Europe have sparked a race to develop in vitro alternatives to tests involving animals.

Plans by the European Commission (EC) to test up to 30,000 substances by 2012 would stretch available animal-testing resources to the limit — and draw the ire of animal-rights protesters, observers say.

So researchers are calling on governments to use the screening plan as an incentive to ramp up the development of other tests that would use, for example, human skin cells to screen the substances in a test tube.

Currently, most toxicity testing is done in vivo using fish, mice or rats in contract research laboratories. By some estimates, 12 million extra animals would be needed for the testing proposed in an EC white paper, Strategy for a Future Chemicals Policy, that was published in February 2001.

But a report prepared by the European Centre for the Validation of Alternative Methods (ECVAM) in Ispra, Italy, says that with more funding for validation studies and infrastructure, alternative methods now being developed could replace animal tests, or at least greatly reduce the number of animals used in initial pre-screening of chemicals, by 2012. The report by ECVAM, which coordinates the validation of alternative testing methods in Europe, says that more research into areas such as the effects of toxicity on reproduction and of 'endocrine disruptors' could help to develop non-animal tests in areas that currently lack alternatives.

But some industrial researchers - many of whose employers oppose the EC's screening plan - are sceptical. "It is highly unlikely that we will be able to replace in vivo tests for the most complex effects, such as carcinogenicity or birth defects, within ten years," says Phil Botham, head of human safety at Syngenta's toxicology laboratory in Macclesfield, UK. A timescale of up to 30 years would be more realistic, he says.

"Pouring new money into in vitro research is not the solution," Botham says. "Much of the current in vitro research is done by researchers who don't understand toxicology," he adds, calling for the European Union (EU) to accept more guidance from industry on the sort of toxicological research that it ought to support.

Michael Balls, the retired head of ECVAM who edited the report, says that efforts to get alternative methods approved - which typically, he says, takes six years - are being hampered by a lack of EU funds for validating the methods.

Hella Lichtenberg, a biologist at the University of Bonn in Germany and coordinator of a consortium that is developing yeast

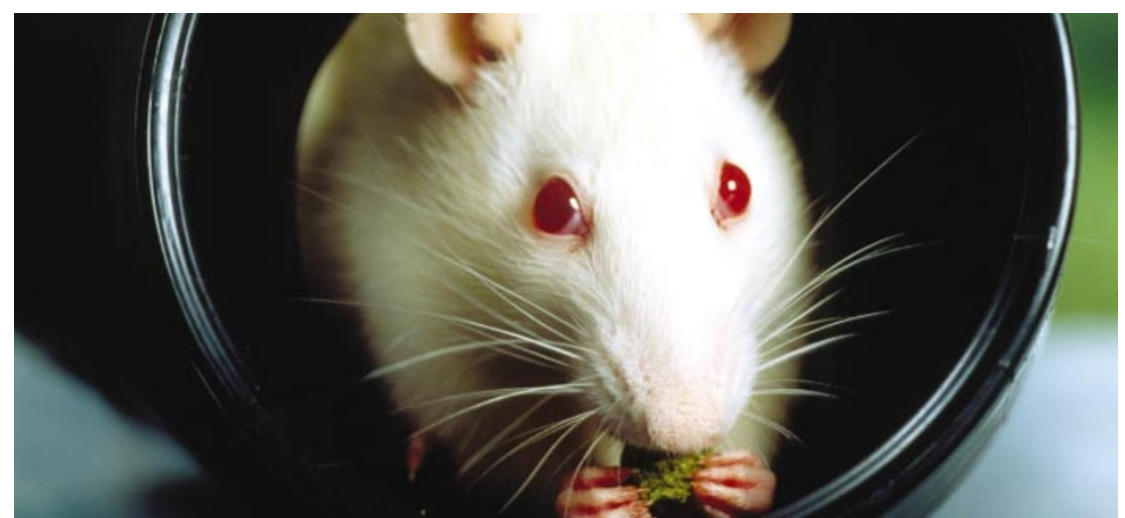

Testing time: plans to screen 30,000 chemicals for toxicity may require millions more animals.

expression technology as a non-animal method for pharmaceutical and toxicological screening, agrees that the EU should be funding projects for longer, so that they can be validated. "The time-consuming validation process requires additional funding to ensure that promising projects are kept running," she says.
The EC's proposal, which has yet to be accepted by EU governments, would aim to test the toxicity of industrial chemicals that were sold in bulk before 1981, when testing requirements for new chemicals came into force.

http://ihcp.jrc.cec.eu.int/Activities/ACTVali/ ACTVali.html

\section{Japan lays out 55-point patent plan}

\section{David Cyranoski, Tokyo}

The Japanese government has unveiled a plan to tighten controls on intellectual property - and encourage reluctant researchers to apply for patents.

The 55-point plan, which was published on 3 July by Prime Minister Junichiro Koizumi's Strategic Council on Intellectual Property, aims to establish graduate programmes to teach intellectual-property rights. It also offers the courts guidelines on the appropriate punishment for patent infringements, and a framework for implementing an agreement reached last month with the United States on mutual recognition of materials used in patent examinations. It also sets out rules for the transfer of tools and materials between researchers and research institutions.

"There are still many things to be done, but this is a milestone," says Takafumi Yamamoto, chief executive of the Center for Advanced Science and Technology Incubation, a company that patents inventions at the University of Tokyo. "This is the first sign of a clear direction for the use of intellectual property in Japan," he says.

Some say that the package will make it easier for researchers to patent their innovations and profit from them. Since 1999 Japanese law has allowed, but not required, funding agencies to yield patents to researchers or their institutions. Critics say that many funding agencies have retained control of patents, but the new measures strongly encourage them to hand over control to research institutions.

The package broadly reflects proposals put forward by the National Forum for Intellectual Property Strategy earlier this year (see Nature 415, 354; 2002), although some elements are missing. "The proposals include provisions to strengthen education in patent law, but they don't include measures for bringing scientists into law classes," complains Koichi Sumikura, a specialist in intellectual property at the National Graduate Institute for Policy Studies in Tokyo and a member of the forum.

Some researchers fear that the government's obsession with intellectual property may lead it to fund science on the basis of patents, instead of quality. The reforms are scheduled to come into effect in 2004 as part of a shake-up of Japan's universities. Subsequently, the proposal document calls for a "distribution of resources to universities and public research institutions that appropriately reflects an evaluation of the institutions' progress in attaining and making use of patents".

"Rewarding patents is good, but not if it means a decrease in funding for basic science," says Keiichi Kodaira, president of the Graduate University for Advanced Studies in Kanagawa. 